\title{
Los monumentos y sitios del Ejército de los Andes: materialidad, representación y uso social de un patrimonio histórico- militar del valle de Aconcagua, Chile
}

The monuments and sites of the Army of the Andes: materiality, representation and social use of a historical-military heritage of the Aconcagua Valley, Chile

Ms. CRistian Urzúa Aburto

Investigador Área Patrimonio Histórico-Cultural, Centro de Investigación en Turismo y Patrimonio, Chile X cristianurzua@cityp.org [orcid.org/0000-0002-5469-0583]

\begin{abstract}
RESUMEN
Desde inicios del siglo XIX, con los procesos de independencia nacionales, los Estados latinoamericanos comenzaron un proceso de auto-construcción a partir de referentes simbólicos, con los cuales se honraba a la patria a través del recuerdo de acontecimientos y personajes gloriosos. La construcción de monumentos constituye un dispositivo fundamental para asentar aquel imaginario patrio desde entonces hasta el día de hoy. En este contexto, este estudio busca identificar y analizar los monumentos y sitios asociados al Cruce del Ejército de los Andes, una gesta latinoamericana que ha dejado una vasta materialidad patrimonial, en particular, en el valle de Aconcagua en Chile, donde se encuentra la mayor parte de este legado. Junto a ello, este estudio busca determinar las representaciones históricas, alegóricas y legendarias que evocan dichos monumentos y sitios, así como los usos actuales de este patrimonio histórico-militar, que enuncia una memoria histórica nacional, un factor de identidad local y un elemento de desarrollo económico.
\end{abstract}

PALABRAS CLAVE: monumentos, Ejército de los Andes, Cruce de los Andes, patrimonio histórico-militar, Valle de Aconcagua.

\section{ABSTRACT}

Since the beginning of the 19th century, with national Independence processes, the Latin American States began a process of self-construction from relating symbolic, with which is honoring the homeland through the recollection of events and glorious characters. The construction of monuments is an essential device to settle that imaginary homeland since 
then until today. In this context, this study seeks to identify and analyze the monuments and sites associated with the Army of the Andes Crossing, a Latin American epic that has left a vast heritage materiality, in particular, in the Aconcagua valley in Chile, where the greater part of this legacy. Next to it, this study seeks to determine the historical, allegorical and legendary representations that evoke these monuments and sites, as well as the current uses of this historical military heritage, setting forth a national historical memory, a factor of local identity and an element of economic development.

KEY WORDS: monuments, Army of the Andes, Crossing of the Andes, historical-military heritage, Aconcagua Valley.

\section{INTRODUCCIÓN}

El Cruce del Ejército de los Andes fue una de las hazañas militares más célebres en la historia de la independencia americana, dejando en Argentina y Chile una importante red de monumentos y sitios de memoria por parte del Estado, el Ejército, el gobierno local y la ciudadanía. Cada año se realizan actividades conmemorativas y recreaciones que recuerdan este episodio histórico-militar, especialmente en el valle de Aconcagua, donde ocurrieron las batallas decisivas que pavimentaron el camino de la emancipación nacional. La investigación en torno a este hecho ha producido cientos de escritos históricos, pero indagaciones que aborden directamente su patrimonio cultural son escasas. El tema es relevante por la activación reciente de este patrimonio tras la celebración del Bicentenario del Cruce de los Andes el año 2017, lo cual genera una reactivación institucional y sociocultural que habla de la importancia y vigencia de estos sitios, y que invitan a la reflexión.

El propósito de esta investigación es estudiar cómo los monumentos y sitios del Ejército de los Andes en el valle de Aconcagua $^{1}$ se vinculan a la memoria local-nacional a través de representaciones, narrativas y usos particulares. Por una parte, se busca estudiar la espacialización de la memoria y su relación con la construcción de monumentos, sitios alegóricos y colecciones museales y, por otra, analizar los usos políticos, sociales y económicos que esta materialidad produce. Se integra así lo tangible e intangible, es decir, la arquitectura, el paisaje, las organizaciones y la comunidad para generar significados y representaciones en torno a este hecho histórico.

Este estudio sostiene que para el Ejército y el Estado de Chile, los monumentos y sitios vinculados al Ejército de los Andes constituyen dispositivos que buscan estructurar simbólicamente una conciencia nacionalista y afirmar el poder estatal. Conjunta a esta tesis, se añade que los municipios y la ciudadanía recrean y retroalimentan históricamente estos

\footnotetext{
Para efectos de este estudio, el valle de Aconcagua comprende a las provincias de Los Andes y San Felipe de Aconcagua, de la V región de Valparaíso, junto a la parte más septentrional de la comuna de Colina, donde se ubica la cuesta de Chacabuco, perteneciente a la región Metropolitana de Santiago.
} 
procesos produciendo un imaginario y una ritualidad desde lo local, integrándolos en su bagaje patrimonial como referentes culturales que conforman una identidad. Por lo anterior, la monumentalización del Cruce de los Andes y ritos asociados despliegan no sólo actos de poder que generan discursos hegemónicos, pues éstos pueden ser resignificados desde lo local mostrando así una heterogeneidad simbólica y utilitaria. Como indica Nora (2009), los lugares de memoria pertenecen a dos reinos, que le confieren interés y complejidad, son "simples y ambiguos, naturales y artificiales, abiertos inmediatamente a la experiencia más sensible y, al mismo tiempo, fruto de la elaboración más abstracta”. Son lugares -dice- en los tres sentidos de la palabra, "material, simbólico y funcional, pero simultáneamente en grados diversos" (p. 32).

La investigación ocupa un enfoque histórico y antropológico, en base a trabajo de campo y estudio de fuentes primarias y secundarias, a través de etapas sucesivas, desarrolladas entre los años 2016 y 2019, consistentes en: a) identificación, registro y caracterización de monumentos y sitios; b) contextualización histórica, social y geográfica con fuentes documentales y bibliográficas; c) identificación y análisis de narrativas, ritos y usos asociados a este patrimonio histórico; d) observación participante en actividades conmemorativas (actos cívico-militares y cabalgata del Bicentenario 2017); e) participación en actividades de formación y difusión (talleres, charlas y seminarios); y f) entrevistas libres y semiestructuradas con actores claves en el proceso del mundo político, cultural, social, militar y empresarial.

Los monumentos y sitios han sido estudiados por la historia del arte, la arquitectura, la historia o la geografía, entre otras disciplinas, configurando así una amplia gama de conocimientos que van desde aspectos tan concretos como su materialidad hasta aquellos intangibles como su significado. Se reconoce un conjunto de estudios que se centran en la conformación del Estado-nación y los dispositivos que contribuyen a su legitimación, mientras que otros ponen énfasis en cómo específicamente la estatuaria y el acto conmemorativo en torno a ellos contribuyen a tal objeto.

El estudio de Hobsbawm y Ranger (2002) es sugerente al analizar la ritualidad surgida en la Europa moderna en torno al nacionalismo, donde se desplegaban poderosos actos rituales usando antiguos y nuevos símbolos como procesiones, repique de campanas, saludos de armas o delegaciones gubernamentales, entre otras manifestaciones (p. 13). Los autores acuñan el concepto de tradición inventada para definir este repertorio como un "grupo de prácticas, normalmente gobernadas por reglas aceptadas abierta o tácitamente y de naturaleza simbólica o ritual, que buscan inculcar determinados valores o normas de comportamiento por medio de su repetición, lo cual implica automáticamente continuidad con el pasado" (p. 8).

Similar afirmación es la que ofrece Anderson (2006) al estudiar el origen de los nacionalismos, aunque yendo más allá al indicar que la nación es una construcción en base a procesos históricos complejos que influyen en el sentido de pertenencia a ésta, conformando a través de ciertos dispositivos (como libros, periódicos, censos, mapas y museos) una 
comunidad imaginada. Pero esta comunidad tiene su base en componentes en los que se vive el nacionalismo, como es la estatuaria pública, uno de los modos en que la base material de la imaginación nacionalista emerge y es estructurada simbólicamente (Johnson, 1995, p. 52). De este modo, al establecer la relación entre construcción de monumentos y políticas nacionalistas se entiende a esta materialidad como un vehículo que produce subjetividades en el contexto de construcción del Estado-nación.

Un factor ausente en la ecuación de Johnson es la dimensión histórica de los monumentos, cuyas representaciones pueden cambiar con el tiempo. Atkinson y Crosgrove (1998), investigando el monumento a Vittorio Emanuele II en Italia, observan que desde los gobiernos liberales hasta la actualidad existe una narrativa cambiante y hasta contradictoria, que significa y resignifica históricamente al monumento; primero, como símbolo de la unidad italiana, y, luego, representativo de valores fascistas o como un homenaje a los caídos en la Segunda Guerra Mundial. Similar al caso italiano, estas interpretaciones divergentes son también consideradas por Foxall (2013), quien analiza la relación entre memoria y materialidad expresada en el caso de los monumentos de la Rusia post-soviética, en particular de la estatua del General Alexei en Stavropol, que revela las tensiones inter-étnicas por la interpretación en torno al monumento, que para algunos representa el símbolo del nacionalismo ruso, mientras que para otros constituye un emblema de la represión estatal.

Una u otra significación en torno al monumento depende de una comunidad que le da vida y significado. Sin el rito del acto conmemorativo éste pierde su fuerza y vigencia y, por tanto, deja de existir para las personas. Es por ello que los monumentos se perpetuán al provocar un tipo de recreación que genera una especie de centro de gravedad para su repetición cíclica (Winkler, Wintrhop-Young \& Wultz, 2002, p. 96). Es por tanto necesario subrayar el papel de los ritos a través de los cuales los monumentos adquieren legitimidad y vigencia, y con los que es posible interpretar los sentidos de una colectividad (Bell, 2009, p. 7). Esta ritualidad, como se ve, está encarnada en personas de carne y hueso, de una comunidad que les da origen, atención y resguardo; y también críticas, por lo que constituyen dispositivos para la generación de identidades por afirmación o negación. Desde la perspectiva de Nora (2009) la memoria es la vida, "siempre encarnada por grupos vivientes", "se nutre de recuerdos borrosos, empalmados, globales o flotantes, particulares o simbólicos; es sensible a todas las transferencias, pantallas, censuras o proyecciones", amenazada no obstante por la sospecha y crítica de la historia (pp. 20-21). Por tanto, aunque existe un relato histórico oficial, éste se entrelaza con la memoria viva de una comunidad que le otorga representaciones y usos a esta materialidad monumental.

Ahora bien, el estudio de los monumentos y sitios del Ejército de los Andes es excepcional en varios aspectos. En primer lugar, no constituye un hito en particular sino una red de monumentos erigidos en tiempos y espacios diversos, distribuyéndose en territorio urbano y rural, entre valle y montaña, convergiendo no obstante en torno a este gran relato histórico del Cruce de los Andes. En segundo lugar, el surgimiento de monumentos, narrativas y actos 
conmemorativos, responde a iniciativas situadas en tres niveles, considerando el punto de vista de la colectividad humana que los construye, interpreta y recrea: a) un nivel nacional que legitima la memoria del Estado; b) un nivel local con la generación de una identidad situada (desde el municipio y la ciudadanía); y c) un nivel internacional, de reconocimiento binacional (chileno y argentino) y continental que complejiza las dinámicas de instauración nacionalistas hacia una narrativa panamericanista. El nivel "a” y "c" genera grandes monumentos y celebraciones oficiales, mientras el nivel "b" a través de la tradición oral produce narrativas y significa estos espacios de manera singular, recreando una identidad local.

En suma, esta investigación estudia la producción de una compleja red de monumentos históricos y fija la mirada en los aspectos locales y nacionales, presentando una interpretación integral sobre la materialidad, significados y usos de los monumentos y sitios vinculados al Ejército de los Andes.

\section{EL ORIGEN DE LOS MONUMENTOS Y SITIOS HISTÓRICO-MILITARES EN CHILE}

Una vez lograda su independencia, las naciones hispanoamericanas echarán mano de distintos recursos para legitimar su poder, lograr la cohesión social de la nación y crear una institucionalidad republicana. Primero, instalando un calendario de conmemoraciones y fiestas patrias, y construyendo luego una serie de monumentos que actúen como punto gravitacional de las celebraciones. Como sostiene Le Goff (1991), la conmemoración se apropia de nuevos instrumentos en el siglo XIX cuando "una nueva oleada de estatuaria, una nueva civilización de las inscripciones (monumentos, letreros en las calles, lápidas conmemorativas colocadas sobre las casas de los muertos ilustres) inunda las naciones europeas" (p. 170). Estos dispositivos operarán como instrumentos de validación de los nacientes Estados republicanos de América Latina y el Caribe.

En Chile, los referentes simbólicos de unidad nacional serán la bandera y escudo nacionales, el himno patrio y un relato oficial que da cuenta de un pasado común, cuyo origen está precisamente en las guerras de Independencia, acontecimiento representado como un esfuerzo colectivo en pos de la liberación del imperio español. La instauración de una trilogía de celebraciones: 18 de septiembre, 12 de febrero y 5 de abril, contribuirá en los primeros años republicanos a fortalecer el discurso patriota (Peralta, 2007). Las guerras externas posteriores (contra Perú y Bolivia) ayudarán también a reafirmar este sentimiento de unidad nacional. Estos y otros mecanismos instalados por las élites fueron arraigando lentamente un sentimiento patrio que fue penetrando en las capas bajas de la sociedad integrándolas en sus proyectos nacionales (Pinto \& Valdivia, 2009).

En las décadas inmediatas al proceso de Independencia nacional pervive un reconocimiento de los sitios históricos y su valor; sin embargo, en el marco de construcción del Estado-nación, por los diversos proyectos en disputa, falta de cohesión interna y tensiones del gobierno central con los gobiernos regionales, se produjeron fuertes conflictos que 
derivarán más tarde en guerras civiles en 1829-30, 1851 y 1859 (Zeitlin, 1984; Salazar, 2006). Esto postergará la construcción de monumentos por la poca claridad de quienes formarían parte del panteón de próceres patrios, aún vivos algunos de ellos. Paralelo se fue gestando un relato a cargo de la historiografía liberal y conservadora, que pese a tener ideas disímiles respecto a la Independencia, coinciden en el carácter apologético y heroico del proceso. Como sugiere Jocelyn-Holt (2016) la historiografía de la Independencia tiene un componente "interpretativo y valórico", además de propuestas "ideológicas, o incluso más, mitificaciones" que construyen "un tiempo primordial y fabuloso" (p. 384). Una vez establecidos los fundamentos narrativos del imaginario nacional, se comienzan a erigir los primeros monumentos.

Con el fin de recordar este pasado glorioso se construyeron monumentos que exaltaban los hechos de armas y a sus héroes militares. Bernardo O `Higgins, uno de sus protagonistas, rechazaba las estatuas personales, pero consideraba necesarias aquellas de carácter supraindividual, especialmente las conmemorativas de batallas que decía "tenían que ser emplazadas en el lugar de los hechos". Para la primera conmemoración de las batallas de Chacabuco y Maipú se encargó la construcción de sendos obeliscos, los que no se llegaron a erigir (Voionmaa, 2005a, pp. 76-77). La construcción de estatuas de los protagonistas demoraría un tiempo, pues seguía aún viva la controversia sobre la figura de O `Higgins (exiliado en Perú) y la reticencia a homenajear a figuras extranjeras como José de San Martín. El hielo se rompe cuando asume la intendencia de Santiago el intelectual liberal Benjamín Vicuña Mackenna, quien señala la necesidad de instalar homenajes a los próceres, en especial a San Martín, argumentando que es una figura sudamericana que trasciende las nacionalidades (Voionmaa, 2005b, p. 54). En efecto, en 1863 se instala una estatua ecuestre dedicada al prócer argentino, en medio de una masiva conmemoración, mientras que en 1872 se inaugura el primer monumento ecuestre en homenaje a O’Higgins (pp. 28-29).

La época del Centenario de Chile (1910) fue prolífica en conmemoraciones y construcción de monumentos. En el contexto de las celebraciones, una exposición retrospectiva en Santiago mostraba "con mucho orgullo la casaca y la espada que Bernardo O'Higgins usó en las Batallas de Chacabuco y llevó a Maipú". El 28 de septiembre de 1910 se coloca la primera piedra en Los Andes en recuerdo de la batalla de Chacabuco, "la más trascendental que los Ejércitos unidos de las dos Repúblicas hermanas, Chile y Argentina, hayan reñido por conquistar su Independencia”. Con ello los monumentos de Chacabuco y de Maipú "se inscriben como precursores en su género en la estética de los memoriales de guerra en el mundo, en que se recuerda supraindividualmente a grandes hazañas, sin referir al protagonismo personal de los próceres" (Voionmaa, 2005b, pp. 77-78).

El Centenario de la batalla de Chacabuco el 12 de febrero de 1917 (Fig. 1), se celebró con gran pompa en la ciudad de Los Andes, con desfiles, discursos y una misa de campaña. Participaron autoridades chilenas, argentinas y uruguayas, los Boy Scouts, el Cuerpo de Bomberos de Los Andes, los veteranos de la guerra del Pacífico y gran parte de la ciudadanía andina. El centro del evento lo constituyó la inauguración de una estatua en honor a José de San Martín, figura emblemática de la gesta histórica, consolidando así la tendencia al culto a los próceres. El 

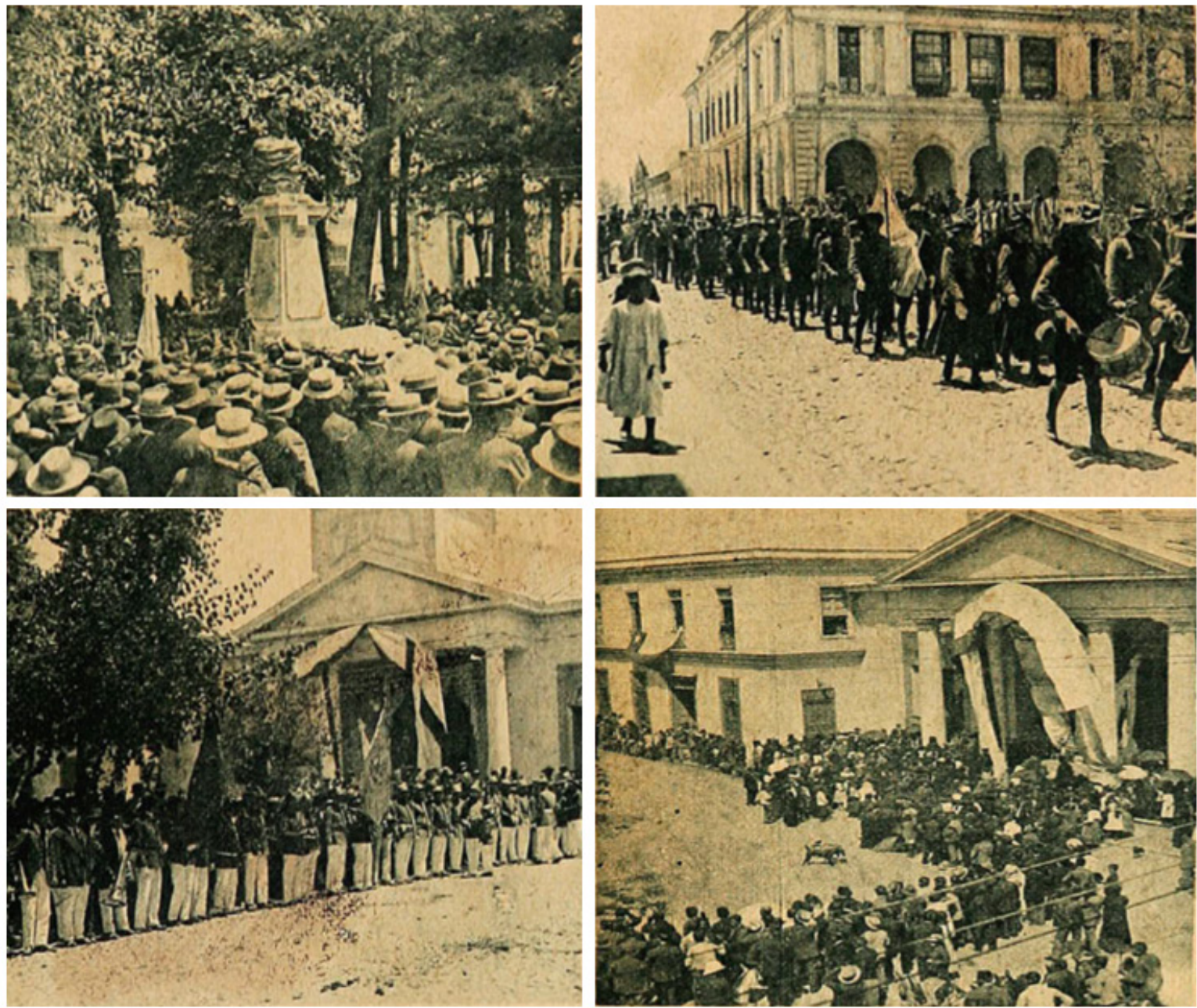

Fig. 1. Conmemoración del Centenario del Cruce del Ejército de los Andes en la ciudad de Los Andes. Arriba

izquierda: Inauguración del Monumento de José de San Martín en la Plaza de Los Andes. Arriba derecha: Los scouts argentinos y uruguayos llegando a Los Andes. Abajo izquierda: Los miembros del Cuerpo de Bomberos y Veteranos del 79, de Los Andes, en la inauguración del monumento a San Martín. Abajo derecha: Vista general de la plaza de Los Andes durante la misa de campaña. Fuente: Delano, 1917.

monumento de Chacabuco como el de San Martín exaltan la gloria del Ejército de los Andes en tierras chilenas, convirtiéndose en sitios de conmemoración de la Independencia hasta nuestros días. Pero no serán los últimos, posteriormente se instalará a lo largo y ancho del territorio una prolífica materialidad monumental.

\section{MATERIALIDAD: MONUMENTOS Y SITIOS \\ DEL EJÉRCITO DE LOS ANDES EN EL VALLE DE ACONCAGUA}

El elemento ordenador de los monumentos y sitios del Ejército de los Andes en el valle de Aconcagua se circunscribe a la ruta trazada por las columnas militares de José de San Martín y Juan 
Gregorio de Las Heras, que ingresaron por los pasos de Los Patos y Uspallata, respectivamente. Los relatos de las batallas y sucesos que tuvieron a su andar, socializados posteriormente entre la sociedad local, provincial y nacional, contribuirán a la patrimonialización de hechos y sitios, transformándose con el tiempo en lugares de conmemoración histórica. Pasos fronterizos, caminos y pueblos estructurarán así un hotspot patrimonial vinculado al Cruce de los Andes y a la Independencia².

La investigación ha permitido identificar fechas emblemáticas donde se ha construido una prolífica materialidad monumental, especialmente durante actos conmemorativos como la celebración del Centenario y Bicentenario nacional (18 de septiembre de 1910 y 2010) y el Centenario y Bicentenario de la batalla de Chacabuco (12 de febrero de 1917 y 2017). Se han realizado allí grandes celebraciones cívico-militares con participación del Estado, el Ejército, el gobierno local y la comunidad. En un principio fueron construcciones sobrias y rústicas; sólo en el último tiempo se han erigido monumentos más sofisticados desde un punto de vista artístico. Predominan las estructuras de piedra y granito, con placas de bronce o mármol, con el fin de hacerlas perdurar. Sin embargo, han sido remozados, resituados, resignificados y hasta reconstruidos por completo, reforzando así su reconocimiento social e institucional.

De acuerdo a la información recabada en el trabajo de campo (ver Tabla 1) se identificaron 62 elementos vinculados al Ejército de los Andes que se distribuyen en ocho de las diez comunas de las provincias de Los Andes y San Felipe, y en la comuna de Colina, perteneciente a la región Metropolitana de Santiago. El número, disposición y concentración espacial de los elementos patrimoniales vinculados al acontecimiento responden a la trayectoria histórica del ejército binacional. Así, las actuales comunas de Putaendo y Los Andes, donde transitaron las columnas de San Martín y Las Heras respectivamente, concentran la mayor cantidad de elementos patrimoniales vinculados al Cruce de los Andes, siguiéndoles las comunas de San Felipe (en especial su centro histórico y el poblado de Curimón), Colina (sitio de la batalla de Chacabuco) y Rinconada de Los Andes (lugar de paso del ejército desde Curimón a la cuesta de Chacabuco). En el resto de las comunas rurales (Llay-Llay, Santa María y Calle Larga) se distinguen bustos de Bernardo O’Higgins en sus respectivas Plazas de Armas. El caso de San Esteban es especial, pues se distingue por la leyenda del sector del "Cariño Botado", que ha originado diversas expresiones patrimoniales en el territorio. A la comuna de Los Andes

\footnotetext{
Hay también un conjunto de monumentos relacionados a la época de la Independencia que explican y contextualizan el proceso en su conjunto. Una vez ocurrida la derrota de Rancagua, el 4 de febrero de 1814, cientos de patriotas emigran hacia Mendoza utilizando el paso cordillerano de Los Andes. En este contexto, el 11 de octubre de 1814 José Miguel Carrera protagoniza el combate de Los Papeles donde defiende la retaguardia de los exiliados que huían hacia Mendoza, originando así un monolito que recuerda el episodio militar. Igualmente, durante la resistencia patriota en el periodo de reconquista (1814-1817) destacan las figuras del patriota José Antonio Salinas y Manuel Rodríguez, quienes sostuvieron acciones de espionaje y guerrilla por encargo de San Martín. Por estos hechos, la casa de José Antonio Salinas en Putaendo es declarada Monumento Nacional en 1972, mientras que en memoria de Rodríguez se erige un monumento en la avenida de Chacabuco de San Felipe.
} 
Tabla 1. Monumentos y sitios vinculados al Cruce del Ejército de los Andes en el Valle de Aconcagua, Chile, 2019.

\begin{tabular}{|l|c|c|c|c|c|c|c|c|}
\hline $\begin{array}{l}\text { Elementos / } \\
\text { Comuna }\end{array}$ & Monumentos & Monolitos & $\begin{array}{c}\text { Bustos / } \\
\text { Estatuas }\end{array}$ & $\begin{array}{c}\text { Inmuebles } \\
\text { Históricos }\end{array}$ & Sitios & $\begin{array}{c}\text { Colección } \\
\text { Museal }\end{array}$ & Murales & Total \\
\hline Putaendo & 3 & 3 & 4 & 1 & 6 & 1 & 2 & 20 \\
\hline Los Andes & 3 & 1 & 2 & 1 & 4 & 3 & 1 & 15 \\
\hline San Felipe & 2 & 1 & 1 & 1 & 1 & 2 & 0 & 8 \\
\hline Colina & 1 & 3 & 0 & 1 & 2 & 0 & 0 & 7 \\
\hline San Esteban & 0 & 2 & 1 & 0 & 1 & 1 & 1 & 6 \\
\hline Rinconada & 0 & 1 & 0 & 1 & 0 & 1 & 0 & 3 \\
\hline Calle Larga & 0 & 0 & 1 & 0 & 0 & 0 & 0 & 1 \\
\hline Llay-Llay & 0 & 0 & 1 & 0 & 0 & 0 & 0 & 1 \\
\hline Santa María & 0 & 0 & 1 & 0 & 0 & 0 & 0 & 1 \\
\hline Total & 9 & 11 & 11 & 5 & 14 & 8 & 4 & 62 \\
\hline
\end{tabular}

Fuente: Elaboración propia en base a trabajo de campo.

se le añade el monumento al Cristo Redentor de los Andes, que aunque se encuentra en el paso limítrofe de Uspallata (territorio argentino), constituye un sitio de rememoración histórica y parte fundamental del imaginario andino.

En este espacio se han identificado sitios y estructuras conmemorativas de diversa índole que se han clasificado de la forma que sigue: a) Monumentos. Construcciones de gran envergadura cuyo fin es recordar o engrandecer un acontecimiento o persona, generalmente vinculado a combates y batallas; b) Monolitos. Bloques de piedra sin mayor elaboración con placas explicativas adosadas referentes a batallas, episodios históricos o legendarios; c) Bustos o estatuas. Monumentos que rememoran figuras históricas, héroes locales y nacionales; d) Inmuebles históricos. Sitios donde acontecieron hechos históricos o propiedades donde vivieron algunos patriotas; e) Sitios. De carácter histórico o alegórico. Lugares con o sin monumentos asociados a un relato histórico o legendario; f) Colección museal. Conjunto de objetos históricos o simbólicos instalados en museos; y g) Murales. Expresiones artísticas que interpretan parte de la historia del Cruce de los Andes. Cabe indicar que se han identificado complejos monumentales, es decir, agrupaciones densas de infraestructura monumental como es el caso del sitio de la batalla de Chacabuco o el poblado de Curimón. También se ha identificado materialidad histórica desaparecida, es decir, inmuebles históricos que ya no existen como el cuartel de O’Higgins en San Felipe o monumentos antiguos que han sido reemplazados por nuevas estructuras.

¿Quiénes construyeron los monumentos? Unos tienen un origen estatal con participación del Ejército de Chile, aunque la mayoría procede de una iniciativa del gobierno local y la ciudadanía con la recolección de erogaciones públicas en sus primeros 
tiempos. Actualmente, la construcción e intervención de monumentos se realiza con financiamiento del municipio o el gobierno regional. Junto a los municipios, el Ejército y la comunidad, han participado instituciones como el Instituto de Conmemoración Histórica de Chile, la Corporación de Conservación y Difusión del Patrimonio Histórico y Militar o bien organizaciones locales. En las placas de los monumentos queda consignado el interés de reconocer esta gesta por parte de instituciones chilenas y argentinas. Otro conjunto de valoraciones procede de las declaraciones ciudadanas de Monumento Nacional o Zona Típica de bienes culturales o espacios vinculados a la Independencia nacional. Por lo dicho, hay por lo general una participación transversal de la sociedad en la construcción de estos monumentos.

En síntesis, el Ejército de los Andes y sus acciones en tierras aconcagüinas dieron origen a una serie de monumentos y sitios históricos que tienen y han tenido una alta significación patrimonial (Fig. 2). Para efectos de análisis éstos se han agrupado en cuatro grandes categorías: a) Monumentos de combates y batallas; b) Pasos fronterizos y paradas; c) Monumentos y expresiones patrimoniales urbanas; y d) Musealización del Cruce de los Andes. A continuación se realiza una descripción analítica de estos elementos.
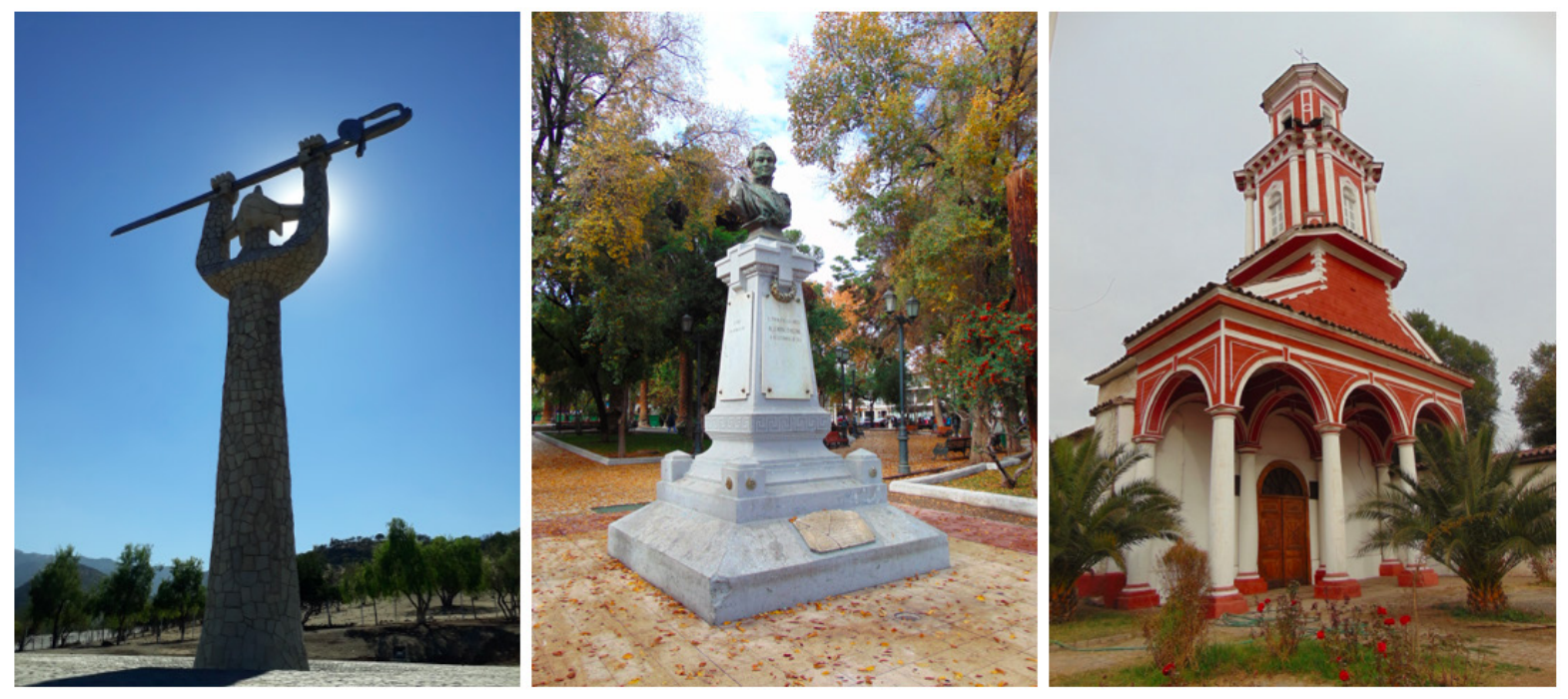

Fig. 2. Monumentos vinculados al Ejército de los Andes. Izquierda: Monumento a la Victoria de Chacabuco en Colina. Centro: Busto de Bernardo O'Higgins en la Plaza de Armas de Los Andes.

Derecha: Iglesia de San Francisco de Curimón, San Felipe. Fotografías del autor, 2017.

a) Monumentos de combates y batallas

Una vez que el Ejército de los Andes atraviesa el macizo cordillerano en dirección al valle de Aconcagua, se llevaron a cabo distintas acciones militares, todas victoriosas, que serán recordadas en la posteridad. El memorial de batalla es el espacio de mayor significancia para el Estado y el Ejército por constituir la más alta expresión de sacrificio 
por la patria y expresión del genio militar de sus generales, brigadieres y subalternos. De la suerte de estas batallas pendía el éxito de la empresa de liberación no sólo de Chile, sino de todo el subcontinente sudamericano, razón por la cual estos espacios fueron los primeros en ser colonizados con monumentos públicos para su conmemoración anual.

Cuatro grandes batallas fueron protagonizadas por destacamentos del Ejército de los Andes y las fuerzas realistas durante febrero de 1817, dando origen a monumentos in situ, estos son: combate de Guardia Vieja (día 2), combate de Achupallas (día 4), combate de Las Coimas (día 7) y batalla de Chacabuco (día 12). Un monumento antecedente de estos acontecimientos es el monolito del combate de Los Papeles (11 de octubre de 1814), acción protagonizada por José Miguel Carrera durante el éxodo masivo de patriotas a Mendoza. La batalla de Chacabuco, junto a la de Maipú, constituye la acción armada decisiva para la consolidación de la Independencia, lo que le ha valido el homenaje más significativo. Se han construido tres monumentos dedicados a esta batalla: el monolito de O'Higgins (denominado también "monolito antiguo") en la cuesta de Chacabuco, el monumento a los caídos de Chacabuco en la ciudad de Los Andes y el gran monumento a la Victoria de Chacabuco instalado en el sitio de la batalla.

El más importante de ellos es el monumento a la Victoria de Chacabuco, construido in situ en 1971 por el prestigioso escultor Héctor Román Latorre. Consta de una estructura de hormigón recubierta de granito de unos 20 metros de altura, que encarna a la victoria, figura femenina que mira hacia el sur, cuyas manos alzan una espada de acero de 15 metros. A este sitio se le han añadido posteriormente un muro alegórico, monolitos y un centro de interpretación donde es posible informarse de los pormenores de la batalla, conformando así un gran complejo monumental que es epicentro de ceremonias oficiales.

\section{b) Pasos fronterizos y paradas}

Seis fueron los pasos a lo largo de Chile donde cruzaron las fuerzas de José de San Martín con el fin de invadir lugares estratégicos y dividir al ejército realista. Las cuatro columnas secundarias salieron entre el 12 y el 19 de enero de $1817^{3}$, mientras que las columnas principales, las de San Martín y Las Heras, cruzaron hacia el valle de Aconcagua entre el 12 de enero y el 8 de febrero, por Los Patos y Uspallata respectivamente. Estas dos columnas han dejado sitios con un alto valor patrimonial que estructurará espacialmente el conjunto monumental del valle de Aconcagua.

Cerca del valle de Los Patos, en el paso fronterizo de Valle Hermoso se erige un monumento con bustos dedicados a O’Higgins y San Martín, con múltiples placas

Las columnas secundarias fueron las de Juan Manuel Cabot, quien salió desde San Juan para tomar La Serena y Coquimbo; Ramón Freire por el paso Planchón para invadir Talca y Curicó; Francisco Zelada, quien cruzando el paso de Come-Caballos ocupó Copiapó; y José León Lemus, quien con un pequeño destacamento cayó sobre la guardia de San Gabriel cerca de San José de Maipo. 
conmemorativas y homenajes. El sitio es punto de encuentro entre delegaciones argentinas y chilenas durante la recreación anual del Cruce de los Andes. Otro hito se encuentra en la convergencia del río Rocín con el estero del Chalaco, sitio denominado también como Los Patos, donde una señalética recuerda el ingreso de la columna sanmartiniana al valle de Putaendo:

"Por este lugar, ingresó al valle de Putaendo el Ejército Libertador de Los Andes un día 4 de febrero de 1817, proveniente desde el Paso los Patos en Valle Hermoso, dando así inicio a la gesta libertadora de este ejército, donde estas montañas guardan la historia del sacrificio de este cruce de más de 3.200 soldados comandado por José de San Martín y por Bernardo O'Higgins".

Por el lado de Uspallata en Argentina se encuentra la escultura del Cristo Redentor de los Andes, obra realizada por el escultor argentino Mateo Alonso e inaugurada el 13 de marzo de 1904 para conmemorar la resolución de los problemas limítrofes entre Argentina y Chile. Una placa al pie del Cristo, de origen chileno, señala: "En el Bicentenario del proceso de Independencia de las repúblicas de Chile y Argentina, en conmemoración del cruce de la cordillera realizado en 1817 por el Ejército de los Andes, símbolo de unidad de argentinos y chilenos". En estos casos, los pasos fronterizos, junto a su valor histórico-patrimonial, constituyen un símbolo de paz y unidad entre Argentina y Chile.

Más allá de las batallas hubo distintos episodios donde el Ejército de los Andes se detuvo a descansar, aperar, pernoctar, orar y organizarse. Estos sitios, según establece el relato, se han convertido en lugares de gran relevancia histórica por lo que se han instalado de igual modo monumentos conmemorativos. Es el caso de la capilla de la hacienda El Tártaro, donde cuenta la memoria local que José de San Martín agradece su intermediación en el paso cordillerano a la Virgen del Carmen. Este hecho ha patrimonializado el sitio con la instalación de un monolito con cuatro placas de bronce, una de las cuales dice: “Aquí José de San Martín ofreció una oración para dar gracias a la Virgen del Carmen por haber cruzado sin problemas estas montañas".

La presencia y acciones del Ejército de los Andes en ciertos lugares les otorga a estos sitios un valor patrimonial, transmitido por la memoria oficial y la tradición popular, significando lugares con relatos particulares, como partes fundamentales del entramado narrativo de la gesta militar en el territorio.

\section{c) Monumentos y expresiones patrimoniales urbanas}

Gran parte de los sectores donde están erigidos los monumentos corresponden a áreas rurales por donde marchó y luchó el Ejército de los Andes. Pero son las ciudades y pueblos, como centros simbólicos del poder, donde se ha instalado una parte importante 
de ellos, con el fin de hacer visible a la ciudadanía la grandeza de la gesta y la ejemplaridad de sus protagonistas. Los monumentos, monolitos, bustos y toda referencia asociada actúan como soportes materiales de la memoria. Carreteras, avenidas y calles reciben los nombres de próceres y batallas ${ }^{4}$. Estas acciones estructuran, testimonian y definen una imagen colectiva que es aprovechada para la articulación de la identidad local. La más alta significación está presente en los títulos que ostentan pueblos y ciudades. San Felipe de Aconcagua es proclamada “Ciudad Heroica” por O’Higgins en 1814 y más tarde recibe el epígrafe de "Ciudad Tres Veces Heroica", mientras que la comuna de Putaendo lleva los títulos de "Primer Pueblo Libre de Chile" y "Capital Patrimonial de Aconcagua".

Simbólicamente el homenaje más importante en la conmemoración de la Independencia es la construcción de monumentos en los centros históricos de ciudades y pueblos. En la Plaza de Armas de Los Andes se alzan dos grandes bustos monumentales de bronce de San Martín y O'Higgins, erigidos en el contexto del Centenario de la batalla de Chacabuco el 12 de febrero de 1917. El pequeño poblado de Curimón es quizás el mejor ejemplo de una alta concentración de elementos patrimoniales ligados al Ejército de Los Andes. Un pequeño monolito de 1980 frente a su iglesia rememora, entre otros acontecimientos, este hecho con la leyenda: "estos muros conocieron a los soldados que ganarían en Chacabuco la Libertad de Chile”. En el Bicentenario del país, el 12 de febrero de 2010, el gobierno de Argentina y Chile instala un nuevo monumento en Curimón: "en conmemoración del lugar de concentración del Ejército de Los Andes en 1817, tras el cruce de la cordillera, previo a la Batalla de Chacabuco", reza su placa de mármol. Todos estos elementos se sitúan frente al ex convento y museo de San Francisco, que guarda piezas históricas y religiosas de gran valor y entre ellas, también elementos alusivos a la llegada del Ejército al poblado.

Los murales son una muestra representativa de la historia y la identidad de los pueblos de Aconcagua, aunando distintos elementos simbólicos que expresan las particularidades de la historia local. En el marco de una mirada histórica general del territorio, la representación pictórica del Ejército de los Andes tiene un foco central. Uno de ellos es el mural "Raíz Profunda" en Putaendo, obra de artistas del taller Rayoceronte, que muestra la historia del pueblo y, en particular, el fragor y drama de la guerra representada en imágenes de cañones, el fuego de las armas y los caídos en combate. Otro es el Mural "El Abrazo de Los Pueblos" en la ex estación de ferrocarriles de Los Andes, pintado por Gregorio de La Fuente en 1954, que representa las relaciones históricas

4 Homenajear a personajes y hechos históricos colocando su nombre a calles y avenidas reafirma la intención de perpetuar la memoria del Ejército de los Andes. Las grandes carreteras que unen Santiago con Los Andes y San Felipe, y esta última con Putaendo, han tomado los nombres de este acontecimiento siendo las principales la autopista Los Libertadores y la carretera Gral. San Martín. En Putaendo, las calles Bernardo O’ Higgins, San Martín, batalla de Chacabuco y la Av. Justo Estay homenajean figuras y batallas. En San Felipe se repiten los nombres anteriores, y se suma Las Heras, combate las Coimas, Coronel Santiago Bueras, entre otros. Semejantes nombres se repiten en Los Andes. Con ello se eterniza en la urbe la memoria de la Independencia nacional y el Ejército de los Andes, convirtiendo a estos espacios en ciudades históricas. 
entre Chile y Argentina, el Cruce de los Andes, la batalla de Chacabuco y las figuras de O’Higgins y San Martín. También en esta ciudad se encuentra un mural cerámico del artista Julio Opazo referente al Cruce de los Andes cerca de la Plaza de Armas.

\section{d) La musealización del Cruce de los Andes}

Los museos locales constituyen dispositivos que guardan la memoria de la Independencia y donde los objetos se presentan como testimonios de la gesta libertadora. Son ocho los espacios museales que resguardan entre sus colecciones objetos de época o alegóricos vinculados al Ejército de los Andes como sables, vestuario o representaciones pictóricas. Las exhibiciones buscan destacar la participación de los patriotas locales y el aporte aconcagüino a la Independencia nacional.

El Museo Histórico de Aconcagua en San Felipe conserva una colección de objetos de época como la espada de José María Portus y una cajuela de viaje perteneciente al patriota José Antonio Salinas, junto a una importante colección de sables y espadas. El museo del Centro Cultural de Putaendo resguarda indumentaria militar (charreteras, bicornio y sables) y el Museo Arqueológico de Los Andes posee una daga rescatada de una excavación en el sitio de la batalla de Chacabuco. Hay otra serie de museos que han realizado pequeños montajes con banderas, pinturas, indumentaria o murales, como una forma de reconocimiento a este acontecimiento, como el Museo de la Viña Monasterio de Rinconada y el Museo Michimalonco de San Esteban. El valor del Museo Franciscano de Curimón radica en la presencia histórica del Ejército de los Andes en ese espacio donde hay pinturas, banderas y elementos alusivos.

Existen dos espacios museales bajo custodia del Ejército de Chile en la comuna de Los Andes. Uno es el Museo Montañés en el poblado de Río Blanco, cuyo objeto es "resaltar la relación de Chile con la cordillera", razón por la que exhibe algunos elementos vinculados a la Independencia. El otro es el Museo del Regimiento Reforzado No 3 de Yungay, que guarda una interesante colección de objetos relacionados con la historia del ejército y la Independencia, que constan de una maqueta recreativa del cruce, objetos, documentos y libros, siendo el elemento más significativo del museo el mausoleo del coronel Nicolás Maruri Gasco (17881866), soldado de la Independencia desde las campañas de 1813, protagonista de las batallas más importantes de ese periodo ${ }^{5}$.

El museo, en el marco de la ciudad histórica que lo rodea, actúa como un repositorio de la memoria local y provincial, relevando la Independencia y el Cruce de los Andes como acontecimientos insoslayables en la historia del valle de Aconcagua. La exposición de estos objetos y alegorías patrióticas en el museo, busca incentivar el desarrollo de una identidad local realzando el papel de los próceres autóctonos que contribuyeron a la consolidación de la Independencia nacional.

De acuerdo a su hoja de servicio exhibida en el museo, figura su participación en el combate de Los Papeles y las batallas de Chacabuco y Maipú; luego se embarcó en la Expedición Libertadora del Perú el 20 de agosto de 1820, entre otras acciones militares. 


\section{REPRESENTACIONES Y NARRATIVAS HISTÓRICO-PATRIMONIALES}

Los monumentos y sitios presentan trayectorias dinámicas, con remozamientos, reubicaciones y hasta reconstrucciones totales. Históricamente han existido miradas disímiles en torno a esta materialidad, pero es el discurso oficial, aquel que resalta la epopeya del acontecimiento y la faceta heroica de sus próceres, el que tiene predominancia en el territorio. Desde esta mirada estatal-nacional los monumentos y sitios históricamente han buscado: a) recordar hitos histórico-militares como parte del relato fundacional de la república; b) destacar a los próceres como sujetos ejemplares, para que la gente emulara sus ideales y acciones (como dar la vida por la patria), fortaleciendo con ello la identidad nacional; y c) imponer la soberanía del Estado demarcando el espacio con monumentos y enseñas patrias frente a posibles invasores extranjeros. Estas ideas han consolidado hoy en día un conjunto de monumentos en torno a este gran relato del Cruce de los Andes, reafirmados periódicamente a través de su conmemoración anual.

La fuerza de los relatos históricos, alegóricos o legendarios, es lo que legitima la construcción de materialidad monumental y la significación de sitios sin monumentos. En su materialidad, disposición y significado, estos relatos nos entregan representaciones diversas desde los actores e instituciones que convergen en torno a este patrimonio. En un principio, hubo reticencia a levantar monumentos personales prefiriéndose las estructuras supraindividuales (como el primer monolito de la batalla de Chacabuco); desde la segunda mitad del siglo XIX comienza el reconocimiento de los próceres de la Independencia (una vez que la generación protagonista de los hechos desaparece); y a partir de la época del Centenario nacional, se levanta y consolida toda una mitología patria, con la definición de figuras (nacionales y locales) y un intensivo proceso de monumentalización y musealización que se expande a lo largo del siglo $\mathrm{XX}$, con declaratorias oficiales (monumentos históricos y zonas típicas) y la erección y remodelación ininterrumpida de monumentos en el espacio público. Hoy en día, el relato se ha complejizado, integrando desde la esfera académica precisiones históricas y nuevos enfoques, mientras que desde la gestión patrimonial se ha enfatizado como nunca antes el rescate de la materialidad, tradiciones e identidades asociadas. Estos procesos, lejos de detenerse, continuarán reproduciéndose en el futuro.

Como se dijo, si bien hay una predominancia del relato oficial, del Estado y el Ejército, en torno a los acontecimientos de la Independencia, de a poco se han desmitificado los aspectos más apologéticos de esta interpretación. Es significativo por ejemplo el aporte de estudios historiográficos críticos que han incluido la mirada de las provincias en el proceso de construcción nacional (Salazar, 2006) o la participación de los grupos subalternos en la Independencia (León, 2011). Relevante en este sentido es el libro de Guerrero (2016) sobre el Cruce del Ejército de los Andes, quien realiza un acucioso trabajo sobre el acontecimiento describiendo no sólo la visión del ejército patriota, 
sino además las vicisitudes del ejército hispano, relegado tradicionalmente por el relato oficial, lo cual ayuda a complejizar la interpretación del proceso en su conjunto ${ }^{6}$.

Desde el punto de vista de la memoria social, otro contrapunto a esta visión tradicional sobre el Cruce de los Andes procede de lo local, donde emergen micro relatos que rescatan una mirada popular y subalterna del acontecimiento, lo cual es indicativo de una apropiación de la gesta por la comunidad y que reivindica parte de su folclore e identidad. Así por ejemplo, el peso histórico de héroes locales como Justo Estay o José Antonio Salinas en Putaendo es exaltado en monumentos, calles con sus nombres y relatos que ensombrecen a la figura del propio Bernardo O'Higgins. En este sentido, los baqueanos y arrieros que actuaron como espías y guías para San Martín poseen un peso cultural gravitante en el territorio, pues son parte fundamental del paisaje y la geografía humana del valle de Aconcagua. La instalación reciente de una estatua en honor al baqueano Justo Estay en el sitio de Achupallas, constituye un reconocimiento de la participación de los sectores populares en el proceso independentista.

De este modo, se reconocen también relatos que poseen un valor patrimonial por una memoria que los ha conservado y traspasado de generación en generación, constituyendo hoy parte del patrimonio cultural intangible de las comunidades. Los relatos identificados por la investigación corresponden a relatos de episodios históricos, asociados a patriotas locales y populares de la Independencia vinculados al arriero Justo Estay, la patriota Águeda Monasterio o José Antonio Salinas y los mártires de Aconcagua; también a mitos y leyendas, sin confirmación histórica, pero que combinan parte de la realidad y lo fantástico. Parte
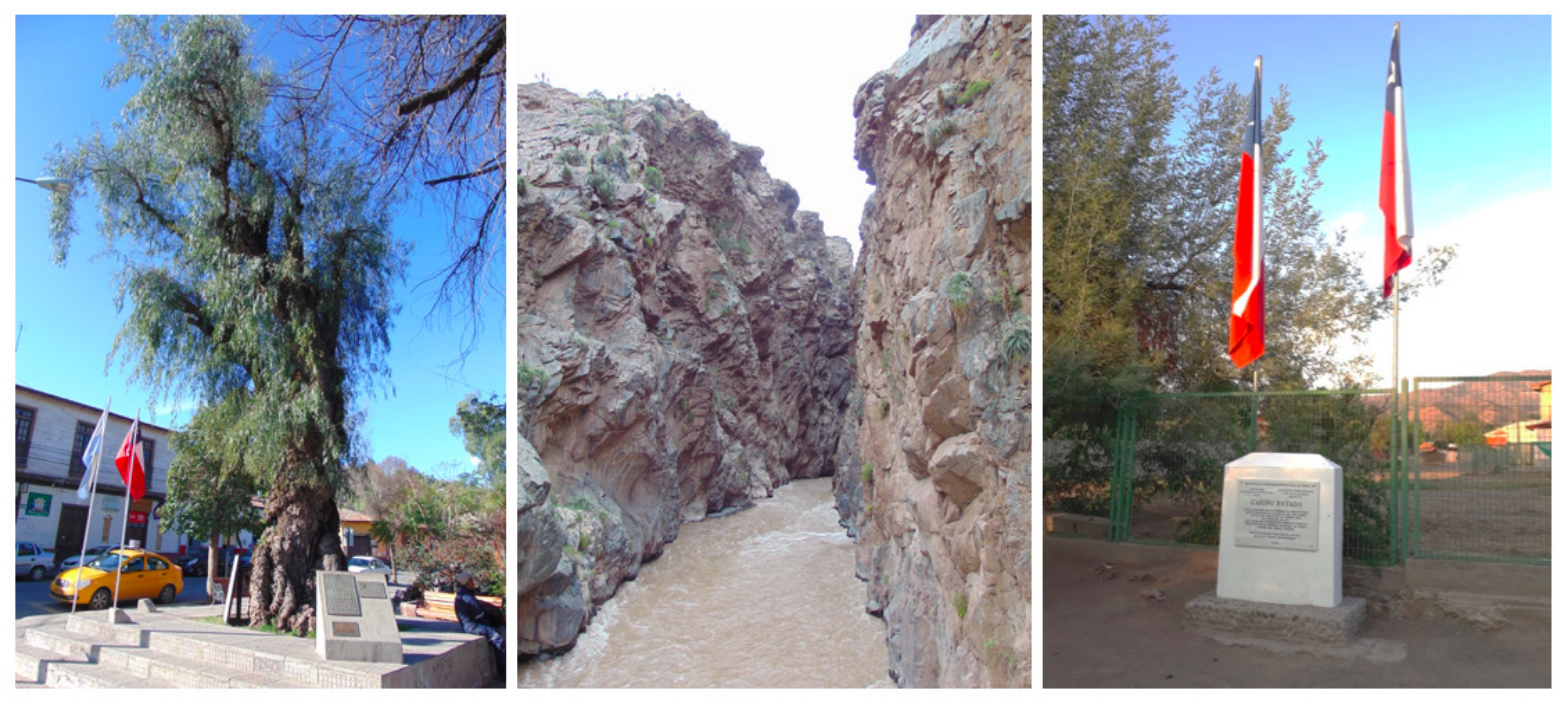

Fig. 3. Sitios legendarios vinculados al Ejército de los Andes. Izquierda: Pimiento Centenario de San Martín en la Plaza de Armas de Putaendo. Centro: Sitio de la leyenda del "Salto del Soldado", Los Andes. Derecha: Monolito en la localidad de Cariño Botado, San Esteban. Fotografías del autor, 2017.

6 Un aspecto relevante es que el texto resulta ser la historia oficial del Cruce del Ejército de los Andes en el contexto de su Bicentenario, auspiciado por el Ejército de Chile, la Corporación de Conservación y Difusión del Patrimonio Histórico y Militar de Chile y la Universidad Bernardo O’Higgins. 
sustancial del folclore local son las leyendas del "Pimiento de San Martín", el "Salto del Soldado" o el "Cariño Botado" (Fig. 3), o bien historias del valle central como los entierros de la Independencia o las correrías de Manuel Rodríguez.

El relato del Pimiento de San Martín, de acuerdo a testimonios recopilados por Carlos Ruiz Zaldívar, señala que llegando el ejército al poblado de Putaendo, los lugareños jubilosos reciben "a los soldados que en un número superior a tres mil realizaron la inigualada proeza de atravesar los altos picachos de la cordillera", obsequiando "chicha y pan amasado entre rancheríos llenos de banderas" a los libertadores. La historia del pimiento proviene de la señora Mariquita Salinas, nieta del patriota José Antonio Salinas, quien aseguraba que San Martín había amarrado su caballo en el pimiento de la plaza, hoy llamada Arturo Prat (Ruiz, 1989, p. 38).

El caso de la leyenda del "Cariño Botado" es también ejemplificador al respecto, pues constituye el mito de los orígenes de este poblado perteneciente a la comuna de San Esteban. Según cuenta Oreste Plath:

Los habitantes de este caserío cercano a Los Andes, supieron que las columnas del Ejército Libertador pasarían por ahí y de inmediato comenzaron los preparativos para hacerles un cariño, sin embargo, cuando todo estaba listo para recibir a los soldados de la libertad, se supo que la columna desvió su ruta, por orden de San Martín, por lo que los preparados quedaron abandonados, el cariño tirado. Y de esta ocasión tomó el nombre de Cariño Botado (Plath, 1983, p. 72).

Un hecho significativo es que en el contexto de las celebraciones del Bicentenario del Cruce de los Andes se hizo una recreación histórica de esta leyenda, donde la comunidad de Cariño Botado recibió a los soldados de la expedición chileno-argentina, quienes se deleitaron con el banquete ofrecido por los lugareños.

El que los monumentos o sitios conmemorativos se sitúen en un espacio físico en particular, deriva de la construcción de un relato que pone en evidencia lo que llamaremos la trasfiguración simbólica por la presencia, es decir, aquella facultad intrínseca que tiene el ejército y sus figuras (San Martín u O’Higgins) para otorgar significaciones a espacios, inmuebles u objetos. Los lugares donde estuvo el ejército, de acuerdo a la crónica y la tradición oral, demuestran el toque patrimonializador de los próceres y de la riqueza de la imaginación popular. Es el caso, por ejemplo, de la figura de San Martín que adquiere una dimensión sobrenatural en torno a los sitios que visitó, y también sobre aquellos que se le atribuye que visitó, como los árboles donde amarró su caballo o los lugares donde descansó. Este acto de presencia sacraliza a los objetos dotándolos de significaciones que lo convierten en un lugar de memoria.

En el relato del Cruce de los Andes el protagonismo se encarna en los generales José de San Martín y Juan Gregorio de Las Heras, los brigadieres Miguel Estanislao Soler y Bernardo 
O’Higgins, el sargento mayor Antonio Arcos (vencedor en Achupallas), el teniente coronel Mariano Necochea (vencedor de Las Coimas) y los patriotas locales José Antonio Salinas, José María Portus o Justo Estay, que tienen una fuerte presencia en la materialidad monumental del valle de Aconcagua, pero es la figura de Bernardo O'Higgins quien se lleva la mayor parte de los reconocimientos. Como el grueso de la operación estaba dirigido por argentinos, existió (y existe) cierta reticencia de reconocer que la Independencia nacional fuese obra de un ejército forastero. Es por eso que junto a San Martín, la contraparte chilena que encarnase la gloria del Cruce de los Andes y Chacabuco sería indiscutiblemente O’Higgins. Considerando que éste jugó un papel relevante, pero subordinado respecto a Las Heras, Soler y San Martín, la estatuaria pública contribuye a igualar la figura de O’Higgins con este último. Ocurre, pues, un realce del prócer chileno, cuyo busto se distribuye en las comunas de Los Andes, San Esteban, Calle Larga, Llay-Llay y Santa María, hegemonizando así el espacio cívico por excelencia: la Plaza de Armas.

Con todo, existen miradas opuestas en torno a los acontecimientos, figuras y reconocimientos de este patrimonio histórico. Hay desacuerdos locales, como por ejemplo, sobre cual fue la casa real del patriota José Antonio Salinas en Putaendo (¿es la casa de Camus No 108, declarada Monumento Histórico, o aquella ubicada frente al Hospital Psiquiátrico donde yace una placa conmemorativa?). Otro conjunto de controversias generales apunta al cuestionamiento al prócer máximo de Chile, Bernardo O `Higgins, respecto a su pericia militar (¿éste se adelantó al ataque en la batalla de Chacabuco o Soler se retrasó en acompañarlo?); también sobre su presunta complicidad en el asesinato de los hermanos Carrera y Manuel Rodríguez. Desde vertientes mucho más críticas, se evidencia en algunos grupos cierto rechazo a la gesta por su carácter inminentemente militar (de una aprehensión de asociar lo militar a la dictadura pinochetista) o en el irrespeto mostrado por algunos jóvenes que vandalizan los monumentos, por nombrar algunos ejemplos, que dan cuenta de voces alternas que tensionan algunos aspectos del relato histórico-militar y de las valoraciones patrimoniales establecidas.

\section{USOS SOCIALES DEL PATRIMONIO HISTÓRICO-MILITAR: RITUALIZACIÓN, PATRIMONIALIZACIÓN Y TURISTIFICACIÓN}

La relevancia de la materialidad patrimonial asociada al Cruce del Ejército de los Andes se relaciona directamente a los intereses de los actores e instituciones vinculados a este patrimonio histórico-militar como son el gobierno nacional, los municipios, el Ejército y las comunidades, que legitiman intereses políticos, definen identidades o conforman estrategias de desarrollo. De este modo, la investigación ha permitido identificar tres usos actuales en torno a este patrimonio cultural asociado al Ejército de los Andes: a) un uso político que reafirma la memoria histórica nacional; b) un uso social identitario a nivel local; y c) un uso económico para el desarrollo turístico del territorio. En conjunto, los usos del patrimonio demuestran el peso gravitante del acontecimiento histórico y la vigencia de los monumentos y sitios asociados. 
Para el Estado, el Ejército y el gobierno local, históricamente la construcción de monumentos es una forma de auto-afirmación que institucionaliza una memoria histórica, parte relevante en la construcción de su relato fundacional. El Cruce de los Andes y la batalla de Chacabuco contribuyeron a la liberación de la dominación hispana y el advenimiento de la república, constituyendo un episodio clave en el proceso de Independencia. Por tanto, para reproducir su potestad soberana, el Estado oficializó el recuerdo de acontecimientos gloriosos y próceres con la construcción de monumentos y el acto repetitivo de su conmemoración anual. Aquí se muestra la concepción conservacionista y monumentalista del Estado que busca "rescatar, preservar y custodiar especialmente los bienes históricos capaces de exaltar la nacionalidad, de ser símbolos de cohesión y grandeza" (García, 1999, p. 23).

La celebración del Cruce de los Andes se distribuye espacial y temporalmente en razón al itinerario del ejército sanmartiniano, siguiendo la senda de los libertadores, cuyos actos conmemorativos en pueblos y ciudades tienen un alcance a la vez local, nacional e internacional. En los primeros años de vida independiente hubo modestos reconocimientos a la gesta patriota, que para el Centenario se convirtieron en actos performativos colosales de carácter transnacional. En la ciudad de Los Andes la celebración del Centenario de la Independencia de Chile en 1910 se dio con gran pompa, desplegando distintos actos para conmemorar al Ejército de los Andes con romerías, desfiles patrióticos o conferencias, entre otras actividades, con la participación de autoridades nacionales y argentinas; instancia cuando se instala la primera piedra del monumento a la Victoria de la batalla de Chacabuco. "La idea de conmemorar el futuro aniversario de la Patria con una obra grande i hermosa, cual es la construcción de un monumento que perpetúe para siempre el nombre de nuestros héroes como igualmente el de los ilustres guerreros San Martín y Las Heras", decía el periódico La Restauración de Los Andes (Donoso, 2007, p. 43).

Más de cien años después, para el Bicentenario del Cruce de los Andes y la batalla de Chacabuco, se desplegó una extraordinaria movilización de recursos materiales y humanos por parte de los gobiernos de Chile y Argentina para conmemorar este episodio histórico entre el 27 de enero y el 12 de febrero de 2017 (Fig. 4). Partieron delegaciones (a pie, montadas y motorizadas) desde el campamento de Plumerillo en Mendoza hacia Chile, siguiendo la senda histórica de las columnas de San Martín y Las Heras, realizando paradas en cada monumento y sitio de esta gesta (Valle Hermoso, Cristo Redentor, San Esteban, Curimón y Los Andes), culminando la travesía en el Monumento a la Victoria de Chacabuco, recorriendo en total unos 490 km (Ejército de Chile, 2017)고. Ese año el acto conmemorativo de Chacabuco se envolvió de solemnidad con la presencia de las más altas autoridades civiles y militares, encabezadas por los presidentes Michelle Bachelet y Mauricio Macri. Hubo discursos, entonación de himnos

El documento oficial indicaba como objetivo: "A 200 años del Cruce de los Andes, resaltar y dar a conocer esta gesta heroica por medio de su recreación, con una fuerza binacional Chileno-Argentina que marchó en dos columnas que se desplazaron por las rutas originales utilizadas por el ejército libertador, comandado por los generales San Martín y O’Higgins. La travesía consideró actividades ceremoniales y de recuerdo histórico en aquellos lugares que testimonian los eventos más trascedentes acaecidos, junto a recreaciones de encuentros en cuatro pasos fronterizos con medios de ambos ejércitos". 
nacionales, izamientos de banderas, disparo de salvas, minutos de silencio y entrega de ofrendas florales y medallas. Ello representa y fortalece además un aspecto que trasciende al hecho mismo de la Independencia, que es la cooperación y paz internacional entre Argentina y Chile.
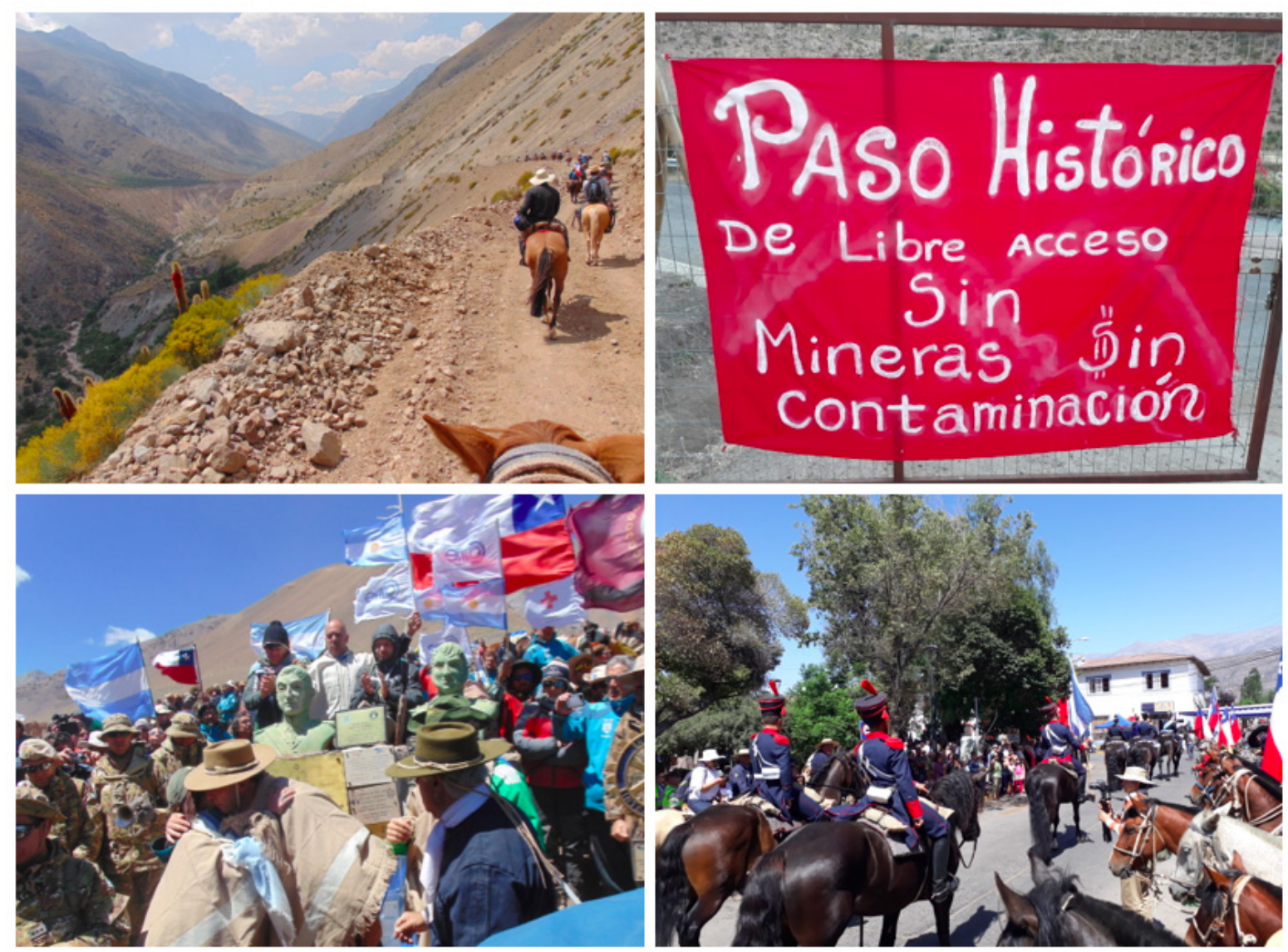

Fig. 4. Cabalgata del Bicentenario del Cruce de los Andes en Putaendo. Arriba izquierda: La delegación civil junto a los arrieros bordeando el río Rocín. Arriba derecha: Cartel en el sector de Los Patos en rechazo de la instalación de la gran minería en Putaendo en la Ruta del Ejército de los Andes. Abajo izquierda: Encuentro de las delegaciones argentinas y chilenas en el paso de Valle Hermoso. Abajo derecha: Desfile cívico-militar en la Plaza de Armas de Putaendo. Fotografías del autor, 2017.

La persistencia estatal en la conmemoración del Cruce de los Andes reafirma su vigencia como parte de una memoria oficial que el Estado pretende perpetuar, pues constituye el hito fundacional de la república. El monumento actúa como la piedra angular de la conmemoración, en torno al cual emergen representaciones colectivas, que por su efecto simbólico resucita al pasado en el rito anual. El monumento opera entonces como una máquina del tiempo que produce una repetición sagrada en torno a sí mismo, especialmente a través del simulacro, estableciendo una prolija performance con disfraces y teatralizaciones que traen el pasado de vuelta reviviendo las aventuras del Ejército de los Andes. 
Estos monumentos, sitios, inmuebles y objetos, son canonizados con instrumentos legales que reconocen oficialmente su valor histórico, a través de los planes reguladores comunales y leyes referentes a monumentos públicos. Las esculturas adquieren legitimación institucional al ser inauguradas a priori con solemnes ceremonias. El Consejo de Monumentos Nacionales es el ente que ha oficializado el reconocimiento de este tipo de bienes culturales tras la elevación de expedientes de patrimonialización procedentes de instituciones, organizaciones y/o la comunidad, que han reconocido su valor postulándolo como Monumento Histórico Nacional o Zona Típica. Entre los valores patrimoniales asociados a los centros urbanos, pueblos y edificaciones históricas, el relato de la Independencia es clave pues contribuye a insuflar su valor patrimonial con su sola asociación ${ }^{8}$. Este patrimonio es aún más reconocido por cuanto las municipalidades, corporaciones y agrupaciones se han preocupado de investigar, conservar y poner en valor todo el patrimonio asociado. La Corporación de Conservación y Difusión del Patrimonio Histórico y Militar ha trabajado por la puesta en valor de la Ruta del Ejército de los Andes con la restauración y construcción de monumentos, la instalación de señaléticas y la difusión de su patrimonio, mientras que la Corporación de Desarrollo Proaconcagua ha desarrollado material educativo y ha organizado actividades conmemorativas, entre otras iniciativas.

Pero según se ha visto, estos reconocimientos no siempre proceden del Estado, sino también del gobierno local y de la comunidad, pues versan sobre elementos identitarios del territorio, que despliegan una patrimonialización in situ, sin reconocimientos oficiales, apropiándose de los monumentos, sitios y relatos. Es por eso que la historia del Cruce y el Ejército de los Andes constituyen hitos históricos que otorgan identidad a los pueblos y a sus habitantes. Es altamente significativo el caso de la comuna de Putaendo, que se ha apropiado culturalmente de la gesta fomentado iniciativas de rehabilitación y construcción de monumentos, así como actos conmemorativos a gran escala territorial. Junto al gobierno local, han apoyado estas iniciativas organizaciones sociales y comunitarias, con especial mención de la Agrupación de Arrieros del Valle Putaendo, portadores de la cultura popular del territorio y protagonistas activos de cada actividad vinculada al "Ejército Libertador".

En la comuna de Putaendo, justamente, esta identidad local se refuerza todavía más con el rescate de sujetos subalternos que participaron de la gesta, como arrieros y baqueanos, que obraron como guías e informantes del Ejército de los Andes. La iniciativa reciente de puesta en valor de los Corrales del Chalaco rescata estas figuras populares de la Independencia, que son todavía parte del paisaje agrario. Como indica el expediente de patrimonialización:

8 Hay cuatro inmuebles y dos espacios vinculados a la Independencia que tienen declaratoria de protección dictada por el Consejo de Monumentos Nacionales. Con la categoría de Monumento Histórico Nacional figuran la Iglesia y Convento de San Francisco de Curimón (declarada en 1971), la Casa del patriota José Antonio Salinas (1972), las Casas y Capilla de la hacienda de Chacabuco (1972) y los Corrales del Chalaco (2018), mientras que el Centro Histórico de Los Andes (2000) y el Centro Histórico y Calle del Comercio de Putaendo (2002) poseen la categoría de Zona Típica. 
Ciertamente en la gesta libertaria se reconoce la incidencia de los habitantes locales, sus habilidades para la travesía y los conocimientos necesarios para un exitoso y furtivo emprendimiento militar. Los baqueanos y arrieros han sido progresivamente reconocidos en ello, lo que intenciona obligadamente a su vez, la vinculación a la infraestructura asociada a la actividad ganadera y comercial existente. En ello, se ha debido reconocer también la existencia de una red de corrales como parte sustantiva de su existencia; donde los referidos al estero Chalaco, adquieren mayor significación, sea por su monumentalidad, pero sobre todo por su emplazamiento estratégico en la localidad de Los Patos; reconocido lugar de paso de las huestes del Ejército Libertador (Corporación CIEM Aconcagua, 2015, pp. 99-100).

Sin embargo, el valor de estos monumentos y sitios no ha sido suficiente para detener la intervención de actividades productivas como la gran minería en el territorio. Se ha generado así un movimiento social llamado Putaendo Resiste para la defensa de una extensa zona amenazada por el proyecto minero Vizcachitas de Andes Copper, que se encuentra realizando sondeos por el que fuera el camino de los libertadores. La iniciativa, según sus dirigentes, convertiría al pueblo en una "zona de sacrificio" que afectaría a la agricultura y la forma de vida local. En el contexto de esta lucha, se ha apelado al valor histórico de la Ruta del Ejército de los Andes (que atraviesa el territorio en disputa) como un antecedente patrimonial para frenar la intervención del paisaje cordillerano.

Otra expresión del uso social del patrimonio por parte del gobierno nacional y local es la habilitación turística de estos sitios. El patrimonio histórico-militar del cruce como elemento identitario es rescatado por las municipalidades y emprendimientos locales y mercantilizado como una estrategia de desarrollo local. Ya desde mediados del siglo XX se ha destacado el valor turístico de este patrimonio histórico-militar, incentivando la visita a ciudades y sitios históricos vinculados a la Independencia nacional (Urzúa, 2017). Al respecto, la revista En Viaje hacia 1963 indicaba que: "Los pueblos amantes del turismo y que ven en esta actividad un rubro importante de su economía, cuidan en forma celosa el mantenimiento de la tradición", agregando que los monumentos que cuentan la "historia y el desenvolvimiento de la nacionalidad, los caserones en que nacieron los héroes y los hombres ilustres y los sitios en que fueron las batallas que recuerdan hazañas y victorias, se guardan con respetuosa emoción" (Jofré, julio de 1963).

El valor histórico de estos sitios y su materialidad, en tanto patrimonio cultural, se han aprovechado como recursos para el desarrollo turístico del territorio, integrándose en las planificaciones globales de las comunas y provincias. Desde entonces se han desarrollado múltiples iniciativas que buscan poner en valor inmuebles y sitios, el rescate de tradiciones o la creación de circuitos y rutas en la perspectiva de generar una afluencia de visitantes al valle de Aconcagua.

En la década de 1980 un estudio pionero reconoce en la provincia de Los Andes a 
la Ruta de San Martín, el Cariño Botado, el Algarrobo de San Martín, el Salto del Soldado y el Monumento del Cristo Redentor como recursos turísticos culturales reconocibles en el territorio (Negrete, 1987, pp. 126-127). La planificación estratégica Aconcagua Turismo 2020 desarrolló un completo estudio del "Destino Valle de Aconcagua", indicando a la Ruta del Ejército de los Andes, sus monumentos y sitios como recursos indispensables para el desarrollo territorial (Aconcagua Turismo 2020, 2013). A nivel local, el Departamento de Turismo de la Municipalidad de Putaendo ha diseñado cuatro rutas que ofrecen atractivos de la comuna, una de las cuales es la Ruta Patrimonial del Ejército Libertador, según la Actualización Plan Comunal de desarrollo de la Comuna de Putaendo, que destaca también el carácter de "Primer Pueblo Libre" de la comuna (Sur Profesionales Consultores, 2015, p. 110). Entre el 2018 y 2019, la Municipalidad de Putaendo, a través de la Pontifica Universidad Católica de Valparaíso (PUCV) y el Centro de Investigación en Turismo y Patrimonio (CITYP), está desarrollando el Plan de Desarrollo Turístico comunal (Pladetur) y declaración de Zona de Interés Turístico (ZOIT), donde se ha reconocido al patrimonio cultural del Ejército de los Andes como un factor clave de la identidad comunal y un recurso estratégico para el desarrollo de productos turísticos.

Esta planificación ha permitido el surgimiento de distintos productos turísticopatrimoniales con el desarrollo de cabalgatas por parte de arrieros y tour-operadores, siguiendo el sendero de los libertadores o la Ruta del Cariño Botado en San Esteban. En cuanto a promoción turística del territorio el relato del Cruce de los Andes es materia imprescindible en guías, folletos o plataformas web donde se incluye el acontecimiento como parte de la identidad del territorio. Reconociendo el valor histórico, cultural, social y turístico de la Ruta Patrimonial del Ejército Libertador, la Municipalidad de Putaendo desde el 2013 ha llevado a cabo distintas iniciativas para su puesta en valor como la postulación al Gobierno Regional del Proyecto "Cabalgata del Bicentenario", que ha permitido el financiamiento de una delegación de personas para recrear el cruce del ejército y participar en los actos conmemorativos del hito fronterizo de Valle Hermoso. Junto a lo anterior, ha propuesto actividades culturales como el "Canto a la Hermandad Chileno Argentina", en el marco del Festival Chaya 2017, y, con recursos municipales y a través de postulación de proyectos, se han intervenido sitios históricos relevantes para la ruta del Ejército de los Andes para su mejoramiento con la construcción de monumentos e instalación de placas (M. Quiroz, comunicación personal, 21 de septiembre de 2017).

\section{CONCLUSIONES}

Los hechos históricos han dejado una huella imborrable en el curso de la vida de sujetos y colectividades. El Cruce de los Andes y la batalla de Chacabuco son episodios que indudablemente han marcado la historia no sólo de Chile y Argentina, sino de todo el continente americano, adquiriendo la categoría de gesta militar. En el contexto de la 
conformación de los Estados hispanoamericanos, el acto conmemorativo de la Independencia se convierte en un dispositivo fundamental para la construcción de la nueva república y su proyecto de unidad e identidad nacional. El mito de los orígenes de la Independencia de Chile actúa así como un conjunto de contenidos que se va revitalizando con su conmemoración anual.

Una forma de alcanzar estos objetivos es a través de la construcción de monumentos que perpetúen la memoria del Estado y el Ejército. Estos vestigios portadores de representaciones no buscan sólo recordar sucesos célebres, sino dar continuidad a los principios republicanos que dieron origen a la revolución criolla. Se va colonizando así el territorio con monumentos, bustos y enseñas patrias que bosquejan hoy el itinerario del Ejército de los Andes en el valle de Aconcagua. Colonizarán también el imaginario colectivo de la población conformando sentidos de pertenencia hacia un territorio, su pasado y su gente. Estos artefactos y referentes simbólicos se han perpetuado ya por dos siglos recreando aquel pasado glorioso hasta nuestros días.

Como señala esta investigación, estos monumentos y sitios no son interpretaciones univocas y ausentes de controversias, pues persisten puntos de vista paradójicos desde lo local y nacional. Por lo dicho, esta valoración no procede unívocamente del Estado, sino que también surge del interés de una comunidad que basa su identidad en esos y otros relatos, se los apropia y reproduce, desde una mirada local y subalterna; y es más, algunas de las expresiones monumentales tienen origen en representaciones y tradiciones de origen popular. El gobierno local retroalimenta dicha identidad y los empresarios, grandes y pequeños, utilizan sus recursos para el fomento productivo, generando así un círculo virtuoso que mantiene viva la historia del Ejército de los Andes. Esto ha puesto en valor a los poblados de Aconcagua generando sinergias para el desarrollo territorial y la revitalización de una identidad local que ha contribuido a conservar su patrimonio histórico.

Si bien esta investigación ha abordado una parte importante de los monumentos y sitios relacionados al Ejército de los Andes, queda todavía estudiar aquellos que están fuera del marco geográfico y temporal examinado, como son los monumentos del lado argentino, las columnas auxiliares y aquellos relacionados a los hechos posteriores a la batalla de Chacabuco, como la batalla de Maipú y la Expedición Libertadora del Perú. Un hecho que pone en vigencia actualmente este patrimonio histórico-militar es que se ha iniciado al otro lado de la cordillera una campaña de declaración de las Rutas Sanmartinianas como Patrimonio de la Humanidad, lo cual exige profundizar el estudio de las expresiones patrimoniales vinculadas a este suceso histórico.

\section{REFERENCIAS}

Aconcagua Turismo 2020 (2013). Plan Estratégico de ordenación y promoción del Turismo en el Valle de Aconcagua 2014-2020. Resumen Ejecutivo. Valparaíso: Centro de Investigación 
Turismo y Patrimonio - Universidad de Valparaíso.

Anderson, B. (2006). Comunidades imaginadas. Reflexiones sobre el origen y la difusión del nacionalismo. México: Fondo de Cultura Económica.

Atkinson, D., \& Cosgrove, D. (1998). Urban Rhetoric and Embodied identities. City Nation, and Empire at the Vittorio Emanuele II Monument in Rome, 1870-1945. Annals of the Association of American Geographers, 88(1), 28-49.

Bell, C. (2009). Ritual Theory, Ritual Practice. United States of America: Oxford University Press.

Corporación CIEM Aconcagua (2015). Corrales del Chalaco. Putaendo, Región de Valparaíso. Expediente técnico para la declaratoria como Monumento Nacional en la categoría Monumento Histórico. Putaendo: I. Municipalidad de Putaendo.

Délano, J. (1917). Las fiestas del Centenario de Chacabuco en Los Andes. Sucesos, 751, 36-37. Donoso, J. (2007). Celebración del Centenario Patrio en la ciudad de Santa Rosa de Los Andes. Santiago de Chile: Centro de Estudios Bicentenario.

Ejército de Chile (2017). 200 años Cruce de Los Andes. Un paso hacia la Libertad. Folleto de divulgación.

Foxall, A. (2013). A contested landscape: Monuments, public memory, and post-Soviet identity Stavropol', Russia. Communist and Post-Communist Studies, 46(1), 167-178.

García, N. (1999). Los usos sociales del patrimonio cultural. En E. Aguilar. Patrimonio Etnológico. Nuevas perspectivas de estudio. España: Conserjería de Cultura - Junta de Andalucía, 16-33.

Guerrero, C. (2016). 1817. De Mendoza a Chacabuco. Santiago: Gráfica Lom.

Hobsbawm, E. \& Ranger, T. (Eds.) (2002). La invención de la tradición. Barcelona: Crítica.

Jocelyn-Holt, A. (2016). La Independencia de Chile. Tradición, modernización y mito. Santiago de Chile: De Bolsillo.

Jofré. M. (1963). Conservemos nuestras reliquias históricas. En Viaje, 357, 1.

Johnson, N. (1995). Cast in Stone: monuments, geography, and nationalism. Environment and Planning D: Society and Space, 13(1), 51-65.

León, L. (2011). Ni patriotas ni realistas. El bajo pueblo durante la Independencia de Chile, 1810-1822. Santiago: Centro de Investigaciones Barros Arana.

Le Goff, J. (1991). El orden de la memoria. El tiempo como imaginario. Barcelona: Paidos.

Negrete, J. (1987). La percepción de los recursos turísticos de la Provincia de Los Andes. Revista de Geografía de Valparaíso, 18, 121-146.

Nora, P. (2009). Pierre Nora en les lieux de mémoire. Santiago: Lom Ediciones.

Peralta, P. (2007). ¡Chile tiene fiesta! El origen del 18 de septiembre (1810-1837). Santiago: Lom Ediciones.

Pinto, J., \& Valdivia, V. (2009). ¿Chilenos todos? La construcción social de la nación (18101840). Santiago: Lom Ediciones.

Plath, O. (1983). Geografía del mito y la leyenda chilenos. Santiago: Editorial Nascimento. 
Quiroz, M. (21 de septiembre de 2017). Entrevista a Mauricio Quiroz Chamorro, Profesional de Apoyo en Temas Patrimoniales de la I. Municipalidad de Putaendo.

Ruiz, C. (1989). Calles de San Felipe. Santiago: Editores Hnos. Arancibia y Cía. Ltda.

Salazar, G. (2006). Construcción de Estado en Chile (1800-1837). Democracia de los "pueblos" Militarismo ciudadano. Golpismo oligárquico. Santiago: Editorial Sudamericana.

Sur Profesionales Consultores (2015). Actualización Plan Comunal de desarrollo de la Comuna de Putaendo. Putaendo: I. Municipalidad de Putaendo.

Urzúa, C. (2017). La imagen turística de la Provincia de Aconcagua. Una mirada histórica desde la revista "En Viaje", 1933-1973. Historia 396, 7(2), 563-595.

Voionmaa, L. (2005a). Escultura Pública. Del monumento conmemorativo a la escultura urbana, Santiago 1792-2004 (Vol. I). Santiago: Ocho Libros Editores.

Voionmaa, L. (2005b). Escultura Pública. Del monumento conmemorativo a la escultura urbana, Santiago 1792-2004 (Vol. II). Santiago: Ocho Libros Editores.

Winkler, H., Wintrhop-Young, G., \& Wultz, M. (2002). Discourses, Schemata, Technology, Monuments: Outline for a Theory of Cultural Continuity. Configurations, 10(1), 91-109.

Zeitlin, M. (1984). The Civil Wars in Chile, or, the Bourgeois Revolutions that never Were. United States of America: Princeton University Press. 